\title{
Effect of dietary lipid supplementation on pre- and post-weaning growth and fat deposition in kids
}

\author{
P. BAS, P. MORAND-FEHR, P. SCHMIDELY, J. HERVIEU \\ Station de Nutrition et Alimentation (INRA), \\ I.N.A.-P.G., 16, rue Claude-Bernard, 75231 Paris Cedex 05 (France)
}

Low subcutaneous adipose deposits on kid carcasses reduce their commercial value. Thus, two experiments were conducted to determine how lipid supplementation can increase fattening in Alpine male kids.

In experiment 1,12 kids received individually, ad libitum a milk replacer $(15 \% \mathrm{~W} / \mathrm{V})$ containing 15.9 (group 1) or $27.0 \%$ (group 2) of fat (especially tallow fat)/DM, from 1 week of age until slaughtering at 7 weeks. In experiment 2,14 kids were given the same milk replacer $(21.5 \%$ fat/DM) until weaning at 6 weeks and from 4 weeks until slaughtering at 14 weeks of age, water, lucerne hay and concentrate were offered ad lib. Concentrate pellets were based on cereals and soyabean-oilmeal in group 3 and on the previous milk replacer powder in group 4 .

In experiment 1 , the level of dry matter intake was higher (6\%: NS) in group 1 than in group 2, but the growth rate was not affected, 213 and $221 \mathrm{~g} / \mathrm{d}$ (respectively for groups 1 and 2). Body fat of group 1 was the least developed in offals $(163$ vs $224 \mathrm{~g} \mathrm{P}: \mathrm{NS}, 89$ vs $161 \mathrm{~g} \mathrm{P}<0.05$, 147 vs $184 \mathrm{~g} \mathrm{P}<0.10,13.1$ vs $19.7 \mathrm{~g} \mathrm{P}<0.05$ respectively for omental, perirenal, mesenteric and pericardic adipose tissues) and in intermuscular leg adipose tissue $(55.8$ vs $69.4 \mathrm{~g} \mathrm{P}<0.10)$ but there were no differences in the two groups for subcutaneous leg and sternal adipose tissues.

During the first 3-week-post weaning period of experiment 2, the level of dry matter intake was lower in group 3 than in group 4 on account of the concentrate intake. In the next period, until slaughtering, the intake of concentrate was similar in the two groups but the hay intake was higher in group 3 than in group 4. Overall growth rate of this post-weaning period was lower in group $3(185$ vs $218 \mathrm{~g} / \mathrm{d} P<0.10)$. As for experiment 1 , kids receiving fat supplementation had more developed adipose tissues in offals $(632$ vs $301 \mathrm{~g} \mathrm{P}<0.01,424$ vs $136 \mathrm{~g} \mathrm{P}<0.01,494$ vs $220 \mathrm{~g} \mathrm{P}<0.01,35.4$ vs $20.7 \mathrm{P}<0.10$ respectively for omental, perirenal, mesenteric and pericardic adipose tissue of groups 4 and 3) but not in sternal subcutaneous adipose tissue.

Dietary fat supplies resulted in an improvement of postweaning but not preweaning growth rate in Alpine kids. Offals and intermuscular adipose deposits were increased especially in weaned kids, but subcutaneous adipose tissue was not affected.

Key words : Adipose tissue, kid, weaning, lipid.

\section{Effect of diet on the fatty acid profile of adipose tissues and muscle fat of kids}

\author{
Zafrira NITSAN, Y. CARASSO, Zipora ZOREF, I. NIR
}

Agricultural Research Organization, The Volcani Center and The Hebrew University of Jerusalem, The Faculty of Agriculture, Rehovot (Israel)

The purpose of the present work was to study whether the composition of the food affects the fatty acid profile of adipose tissues and muscle fat and whether changes in the fatty acid profile are reflected in sensory quality.

Saanen kids were divided into 4 groups of 6 kids each. The kids were fed 1) milk replacer only, 2) milk replacer containing $30 \%$ heat treated starch and soyabean protein concentrate mixture, 3) milk replacer and elevated amounts (up to $60 \%$ ) of raw starch and soyabean protein mixture or 4) milk replacer until the age of 28 days and had free access to dry concentrate 